\title{
HHEX wt Allele
}

National Cancer Institute

\section{Source}

National Cancer Institute. HHEX wt Allele. NCI Thesaurus. Code C114958.

Human HHEX wild-type allele is located in the vicinity of 10 q23.33 and is approximately 7 $\mathrm{kb}$ in length. This allele, which encodes hematopoietically-expressed homeobox protein HHEX, plays a role in transcriptional regulation. 